\title{
Hubungan Dukungan Keluarga dengan Tingkat Harga Diri pada Penderita Stroke di Rumah Sakit Umum Royal Prima Medan
}

\author{
Yusmawarnita Zai ${ }^{\mathrm{a}^{*}}$, Kandrinus Bu'ulolo ${ }^{\mathrm{b}}$, Novy Fajariani ${ }^{\mathrm{c}}$, Yasozatulo Hulu ${ }^{\mathrm{d}}$, \\ Ruslan Efendi Gulo ${ }^{\mathrm{e}}$, Eva Latifah Nurhayati ${ }^{\mathrm{f}}$ \\ Fakultas Keperawatan dan Kebidanan, Universitas Prima Indonesia, Medan 20111, Indonesia \\ ayusmawarnita98@gmail.com*, ${ }^{\mathrm{a}}$ kandrinuspashter@gmail.com, ${ }^{\mathrm{c}}$ fajarianinovy1@gmail.com, ${ }^{\mathrm{d}}$ yasozatuloh@gmail.com, \\ eruslangulo98@gmail.com, ${ }^{\mathrm{f}}$ nurhayati_latifah@yahoo.com \\ * corresponding author
}

ARTICLE INFO

Keywords

Family support

Level of self-esteem

Stroke sufferer

\section{ABSTRACT}

Stroke is a condition where a part of the brain is suddenly disturbed which is caused by a lack of blood supply, which causes an inhibition of metabolic processes. As a result of a stroke affects the psychological function of the patient, so the patient feels his level of self-esteem decreases or is low. The role and support of families play an important role in the rehabilitation process to provide health services for stroke patients. The aim is to find out the relationship of family support with the level of self esteem (self-esteem) in stroke patients at the Royal Prima Medan Hospital in 2019. The design used a "cross sectional study" approach with a population of 2,690 people. Samples were stroke patients at RSU Royal Prima medan, as many as 25 respondents using accidental sampling techniques and questionnaires as research instruments. The test used is the chi-square test. The results of the study Based on the chi-square test found $\mathrm{p}$ value $(<0.05)$ statistically shows that there is a relationship between family support and the level of self esteem (self-esteem) in stroke patients specifically there is a relationship between informational support $(\mathrm{p}$-value $=0.009)$, assessment support ( $\mathrm{p}$-value $=0.003)$, Instrumental support is obtained ( $\mathrm{p}$-value $=0.009)$, Emotional support (p-value $=0.004$ ) with the level of self esteem (selfesteem) in stroke patients. This research shows that good family support will positively impact the level of self esteem (self-esteem) in stroke patients.

\section{Pendahuluan}

Stroke merupakan suatu keadaan dimana bagian otak terganggu secara tiba-tiba yang disebabkan oleh pasokan darah, kerusakan atau kematian sel-sel otak di dalam jaringan otak disebabkan oleh kurangnya aliran darah sehingga menyebabkan terhambatnya proses metabolisme sel-sel saraf, kematian sel-sel otak ini dapat berjalan perlahan-lahan sehingga mencapai titik kematiannya [1].

Stroke dikenal sebagai penyebab kematian kedua setelah penyakit jantung, yang ditandai dengan adanya kerusakan pada jaringan otak yang diakibatkan karena kurangnya suplai darah ke otak ditandai dengan pecahnya pembuluh darah dan kerusakan jaringan otak. Menurut World Health Organization (WHO) tahun 2014, jumlah penderita stroke per individu berdasarkan usia dan jenis kelamin yaitu, perempuan berusia 18-39 sebanyak 2,3\% dan usia 40-69 sebanyak 3,3\%. Sedangkan laki-laki yang usianya 18-39 diperkirakan sebanyak 2,4\% dan usia 40-69 diperkirakan sebanyak 2,9\% [2].

Berdasarkan data Riskesdas (2013) di Indonesia penyakit stroke berdasarkan diagnosis kurang lebih sebanyak 1.236 .825 orang (7\%). Jika dilihat dari gejala berdasarkan diagnosisnya diperkirakan sebanyak 2.137.941 orang $(12,1 \%)$. Di provinsi Jawa Barat jika dilihat berdasarkan 
diagnosis/gejala mempunyai estimasi penderita terbanyak dengan jumlah 238.001 orang $(7,4 \%)$, dan 533.895 orang $(16,6 \%)$, sedangkan penderita yang paling sedikit yaitu di provinsi Jawa Barat dengan jumlah 2.007 orang $(3,6 \%)$ dan 2.955 orang $(5,3 \%)$.

Secara umum, stroke dikelompokan menjadi dua jenis yaitu, stroke iskemik disebabkan oleh aliran darah ke otak yang terhambat atau tersumbat dan stroke hemoragik disebabkan oleh pecahnya pembuluh darah otak sehingga terjadinya perdarahan di otak[3]. Adapun gejala stroke adalah rasa kebas atau mati pada bagian wajah, dan bagian ekstremitas. Ciri khas kehilangan penglihatan atau yang disebut dengan stroke mata, pasien seperti orang kebingungan, mengalami kesulitan berjalan dan kehilangan keseimbangan serta sulit berbicara [4]. Akibat serangan stroke mempengaruhi fungsi psikologisdari pasien, pasien merasa dirinya cacat dan kecacatan itu menyebabkan citra diri terganggu, merasa diri tidak berguna, jelek, mememalukan, tidak mampu melakukan kegiatan seperti orang normal sehingga pasien merasa tingkat harga diri menurun atau rendah [5].

Peran dan dukungan keluarga berperan penting terhadap proses rehabilitas pada penderita stroke. Hal ini disebabkan karena pada orang-orang yang mengalami stroke, dalam melakukan kegiatan sehari-hari akan sangat tergantung pada orang lain, terutama keluarga terdekat dan juga lingkungan sosial sekitar [6]. Dukungan keluarga satu-satu nya tempat yang sangat penting untuk memberikan dukungan pelayanan kesehatan seperti dukungan instrumental, dukungan informasional, dukungan penilaian dan dukungan emosional[7].

Menurut Ghufron \& Risnawati (2018) harga diri adalah tingkat penilaian yang positif atau negatif pada diri seseorang, harga diri merupakan evaluasi seseorang secara positif terhadap dirinya sendiri dan juga dapat menghargai dirinya dengan cara yang negatif. Fungsi keluarga adalah keluarga didefinisikan sebagai penekan tugas-tugas dan fungsi psikososial, mencakup pemberian perawatan, materi dan pemenuhan peran-peran tertentu yang memfokuskan untuk membantu proses penyembuhan pasien (Lestari, 2012). Untuk itulah anggota keluarga harus memahami apa yang sedang dihadapi pasien. Keluarga harus mampu untuk menerima keadaan dan bisa beradaptasi ulang karna itu merupakan hal yang penting untuk mempertahankan kehidupan dalam menghadapi keadaan baru pasien [8].

Hasil survei awal yang dilakukan di Rumah Sakit Umum Royal Prima Medan, di tahun 2018 ditemukan sebanyak 120 orang yang melakukan fisioterapi, 365 orang yang rawat inap dan 2.205 orang yang rawat jalan. Didapatkan data $65 \%$ dari jumlah keseluruhan yang berobat di rumah Sakit Royal Prima Medan sebanyak 2.690 orang, mengalami tingkat harga diri rendah merasa diri tidak berguna, tidak berharga dan akan terus bergantung pada keluarganya. Berdasarkan permasalahan di atas maka, peneliti tertarik untuk meneliti hubungan dukungan keluarga dengan tingkat self esteem (harga diri) pada penderita stroke RSU Royal Prima Medan tahun 2019.

\section{Metode}

Jenis penelitian ini adalah penelitian survei analitik. Survei analitik merupakan penelitian yang mencoba menggali bagaimana dan mengapa fonomena kesehatan itu terjadi. Kemudian melakukan analisis dinamika korelasi antara fenomena baik anatara faktor resiko dan faktor efek.

Desain penelitian menggunakan "cross sectional study" yaitu identifikasi dua variabel antara variabel independen dan variabel dependen dalam waktu yang bersamaan (Suyanto, 2011) untuk mengetahui hubungan dukungan keluarga dengan tingkat self esteem pada penderita stroke di Rumah Sakit Umum Royal Prima Medan tahun 2019.

Lokasi penelitian dilaksanakan di Rumah Sakit Umum Royal Prima Medan tahun 2019.Penelitian ini dilakukan pada tanggal 02 Juli 2019, setelah mendapatkan surat lulus uji etik dari Fakultas Keperawatan dan Kebidanan Universitas Prima Indonesia, yang bertujuan untuk melindungi dan menjamin kerahasiaan responden.

Menurut Hikmat (2014) populasi adalah semua objek penelitian dan objek yang akan diteliti. Populasi dalam penelitian ini adalah semua pasien stroke yang datang berobat di Rumah Sakit Umum Royal Prima Medan tahun 2019. Jumlah populasi yang ada di Rumah Sakit Umum Royal Prima Medan adalah sebanyak 2.690 orang [9].

Sampel dalam penelitian ini diambil dengan menggunakan teknik accidental sampling adalah teknik penentuan sampel secara kebetulan, yaitu siapa saja yang secara kebetulan bertemu 
dengan peneliti dapat digunakan sebagai sampel, bila dipandang orang yang kebetulan ditemui itu sesuai sebagai sumber data [10].

Penelitian dimulai dengan mengajukan surat permohonan izin pelaksanaan penelitian pada instansi pendidikan program S1 keperawatan, kemudian surat izin yang diperoleh diajukan kepada pihak Rumah Sakit Umum Royal Prima Medan. Setelah mendapat izin, kemudian peneliti mengumpulkan data. Data yang dikumpulkan dalam penelitian ini adalah data primer dengan menggunakan cara pengisian kuesioner.

Dukungan keluarga terdiri dari dukungan informasional, dukungan penilaian, dukungan instrumental, dukungan emosional. Menggunakan alat ukur kuesioner skala Likert dengan 4 item pilihan jawaban sebagai berikut $4=$ selalu $3=$ sering $2=$ jarang $1=$ tidak pernah, untuk pernyaaan positif dan sebaliknya untuk pernyataan negatif [10].

Pengukuran tingkat harga diri dilakukan menggunakan skala Gutman dengan jawaban tegas ya dan tidak yang terdiri dari 25 item pernyataan dengan nilai jawaban ya $=1$ dan tidak $=0$ [10].

Analisis univariat dilakukan dengan setiap variabel yang diteliti dimana masing masingmasing variabel akan dibuat gambaran distribusi dan presentasi. Data tersebut ditampilkan dalam bentuk tabel frekuensi.

Analisis bivariat dilakukan untuk mengetahui hubungan antara variabel independen dengan variabel dependen dengan menggunakan uji chi-square pada program SPSS uji chi-square dengan derajat kemaknaan $(\alpha) 0,05$ jika p lebih kecil dari tingkat signifikan tes $(\alpha)$ yang diharapkan maka H0 ditolak artinya ada hubungan dukungan keluarga dengan tingkat self esteem (harga diri) pada penderita stroke di Rumah Sakit Umum Royal Prima Medan tahun 2019. Jika nilai $\rho$ lebih besar dari tingkat signifikan tes $(\alpha)$ yang diharapkan maka HO diterima, artinya tidak ada hubungan dukungan keluarga dengan tingkat self esteem (harga diri) pada penderita stroke di Rumah Sakit Umum Royal Prima Medan tahun 2019. Kemudian hasil penelitian dilanjutkan dalam bentuk tabel dan dibahas dengan Menggunakan teori dan kepustakaan yang ada.

\section{Hasil dan Diskusi}

\section{Analisa Univariat}

Tabel 1. Distribusi frekuensi dukungan informasional

\begin{tabular}{ccc}
\hline Kategori & $\mathbf{f}$ & \% \\
\hline Dukungan informasional & \\
Baik & 21 & 84 \\
Sedang & 3 & 12 \\
Buruk & 1 & 4 \\
\hline Total & & $\mathbf{1 0 0}$ \\
\hline
\end{tabular}

Berdasarkan tabel 1, diketahui bahwa dukungan informasional dari 25 orang responden sebanyak 21 orang (84\%) memberi dukungan dengan kategori baik, 3 orang (12\%) memberi dukungan dengan kategori sedang dan 1 orang (4\%) memberi dukungan dengan kategori buruk.

Tabel 2. Distribusi frekuendi dukungan penilaian

\begin{tabular}{ccc}
\hline Kategori & f & \% \\
\hline Dukungan Penilaian & & \\
Baik & 17 & 68 \\
Sedang & 6 & 24 \\
Buruk & 2 & 8 \\
\hline Total & & $\mathbf{1 0 0}$
\end{tabular}

Berdasarkan tabel 2, dukungan penilaian dari 25 orang keluarga responden mayoritas memberikan dukungan dengan kategori baik 17 orang (68\%), keluarga responden yang memberikan dukungan sedang 6 orang $(26 \%)$ dan minoritas responden yang memberi dukungan dengan kategori buruk 2 orang (8\%). 
Tabel 3.Distribusi frekuensi dukungan instrumental

\begin{tabular}{ccc}
\hline Kategori & $\mathbf{f}$ & $\mathbf{\%}$ \\
\hline Dukungan & & \\
Instrumental & & \\
Baik & 20 & 80 \\
Sedang & 3 & 12 \\
Buruk & 2 & 8 \\
\hline Total & & $\mathbf{1 0 0}$
\end{tabular}

Berdasarkan tabel 3, dukungan instrumental dari 25 orang keluarga responden yang memberikan dukungan keluarga dengan kategori baik sebanyak 20 orang (80\%), keluarga responden yang memberikan dukungan dengan ketegori sedang 3 orang (12\%) dan yang memberi dukungan dengan kategori buruk sebanyak 2 orang (8\%).

Tabel 4. Distribusi dukungan emosional

\begin{tabular}{ccc}
\hline Kategori & f & \% \\
\hline Dukungan Emosional & & \\
Baik & 20 & 80 \\
Sedang & 2 & 8 \\
Buruk & 3 & 12 \\
\hline Total & & $\mathbf{1 0 0}$ \\
\hline
\end{tabular}

Berdasarkan tabel 4, dukungan emosional dari 25 orang keluarga responden sebanyak 20 orang $(80 \%)$ memberi dukungan dengan kategori baik, yang memberi dukungan dengan kategori sedang sebanyak 2 orang (8\%) dan yang memberi dukungan dengan kategori buruk sebanyak 3 orang $(12 \%)$.

\begin{tabular}{ccc}
\multicolumn{3}{c}{ Tabel 5. Tingkat self esteem } \\
\hline Kategori & f & \% \\
\hline Tingkat Self Esteem & & \\
Tinggi & 15 & 60 \\
Sedang & 7 & 28 \\
Rendah & 3 & 12 \\
\hline Total & & $\mathbf{1 0 0}$ \\
\hline
\end{tabular}

Berdasarkan tabel di atas diakui dari 25 responden mayoritas memiliki tingkat self esteem dengan kategori tinggi 15 orang (60\%), kategori sedang memiliki responden 7 orang (28\%) dan minoritas memiliki tingkat self esteem dengan kategori rendah 3 orang (12\%).

\section{Analisa Bivariat}

Dalam analisis bivariat akan di uji dua hubungan yaitu dukungan keluarga dengan tingkat self esteem yang dibagi menjadi empat hubungan yaitu hubungan informasional dengan tingkat self esteem, hubungan penilaian dengan tingkat self esteem, hubungan dukungan instrumental dengan tingkat self esteem, dan hubungan dukungan emosional dengan tingkat self esteemuji chi-squere dengan derajat kemaknaan $(\alpha)$ 0,05 dimana jika nilai $p$-value $<\alpha$ berarti Ho ditolak dan Ha diterima yang menunjukan bahwa terdapat hubungan antara dukungan keluarga dengan tingkat self esteem, sementera jika $p$-value $>\alpha$ berarti Ho diterima dan Ha ditolak yang menunjukan tidak terdapat hubungan antara dukungan keluarga dengan tingkat self esteem.

\section{Pembahasan}

\section{Hubungan Dukungan Informasional Dengan Tingkat Self Esteem}

Berdasarkan hasil penelitian diketahui bahwa ada hubungan antara dukungan informasional dengan tingkat self esteem (harga diri) pada penderita stroke di RSU Royal Prima 
Medan tahun 2019 pada kategori baik sebanyak 71,4\% responden. Sumber dukungan informasional pada keluarga berfungsi sebagai kolektor dan penyebar informasi dimana keluarga berperan untuk memberikan informasi mengenai kesehatan, pencegahan dan bagaimana cara pemulihannya. Keluarga berperan sebagai tempat perawatan dan kesehatan untuk mengatur, melakukan dan menjalankan fungsi nya dalam merawat anggota keluarga yang sakit [11]

Menurut Fuady (2016) Dukungan keluarga dalam bentuk pemberian informasi seperti keluargan meminta penjelasan kepada petugas kesehatan tentang terapi yang harus dijalani pada pasien stroke, mencarikan keuntungan dan kerugian tindakan rehabilitasi serta mencari informasi tentang jenis rehabilitasi yang sesuai untuk pasien [12].

Menurut asumsi peneliti dukungan informasi dan nasihat serta petunjuk merupakan bentuk dukungan yang paling efektif untuk memengaruhi tingkat self esteem (harga diri) pada penderita stroke hal itu dikarenakan dapat membuat pasien mengerti dan lebih tahu.

\section{Hubungan Dukungan Penilaian Dengan Tingkat Self Esteem (Harga Diri)}

Berdasarkan hasil penelitian diketahui bahwa ada hubungan antara dukungan penilaian dengan tingkat self esteem (harga diri) pada penderita stroke di RSU Royal Prima Medan tahun 2019 pada kategori baik sebanyak 82,4\% responden.

Setyoadi (2017) mengumukakan bahwa dukungan penilaian bertindak sebagai umpan balik terhadap apa yang sudah individu lakukan. Dukungan penilaian ditunjukkan oleh keluarga dengan memberikan pujian kepada pasien stroke ketika pasien mengalami kemajuan dan memberikan semangat serta pendapat kepada penderita dalam memecahkan masalah sehingga pasien tetap merasa dihargai [13]. Berdasarkan asumsi penelitian dukungan penilaian seperti pujian dan kritikan yang diberikan akan meningkatkan self esteem bagi penderita stroke.

\section{Hubungan Dukungan Instrumental Dengan Tingkat Self Esteem (Harga Diri)}

Berdasarkan hasil penelitian diketahui bahwa ada hubungan antara dukungan instrumental dengan tingkat self esteem (harga diri) pada penderita stroke di RSU Royal Prima Medan tahun 2019 pada kategori baik sebanyak 75,0\% responden.

Simbolon (2017) mengemukakan bahwa dukungan instrumental adalah bentuk dukungan yang menyediakan materi yang dapat memberikan pertolongan langsung seperti pemberian barang, makanan dan penyediaan dana serta pelayanan [14].

Berdasarkan asumsi peneliti, dukungan instrumental yang baik seperti penyediaan segala macam kebutuhan dalam menjalankan pengobatan pasien dapat meningkatkan self esteem (harga diri) bagi pasien sehingga proses penyembuhan pasien dapat berjalan dengan cepat dari pada sebelumnya.

\section{Hubungan Dukungan Emosional Dengan Tingkat Self Esteem (Harga Diri)}

Berdasarkan hasil penelitian diketahui bahwa ada hubungan antara dukungan emosional dengan tingkat self esteem (harga diri) pada penderita stroke di RSU Royal Prima Medan tahun 2019 pada kategori baik sebanyak 75,0\% responden.

Menurut Fuady (2016) dukungan emosional dianggap mencegah atau mengurangi efek stres serta meningkatkan kesehatan mental individu atau keluarga secara langsung, Sehingga pasien dapat meningkatkan self esteem (harga diri) karena keluarga ikut berperan dalam masalah yang dia hadapi dengan cara memberikan tempat yang nyaman, mendengarkan keluahan pasien serta memberi perhatian dan kasih sayang kepada pasien. Dimana dukungan keluarga merupakan dukungan interpersonal yang meliputi sikap, tindakan dan penerimaan anggota keluarga, sehingga anggota keluarga tersebut merasa ada yang memperhatikan dan mendukungnya. Pasien stroke sangat memerlukan dukungan keluarga dalam perubahan fisik, mental maupun emosional untuk membantu pasien dalam proses pemulihan sehingga pasien merasa dirinya ada yang memperhatikan dan mempedulikannya [12] [15].

Menurut asumsi peneliti, dukungan emosional yang baik memberikan empati, kasih sayang dan rasa peduli kepada pasien dapat meningkatkan self esteem (harga diri) karena faktor emosi dapat memberikan pengaruh yang positif untuk menciptakan suatu perilaku yang lebih positif.Berdasarkan hasil penelitian yang telah kami lakukan bahwa semua terdapat ada hubungan baik dukungan informasional, penilaian, instrumental dan emosional. Sama dengan hasil penelitian 
yang dilakukan oleh (Fahrizal \& Darliana, 2017) tentang dukungan keluarga dalam merawat pasien stroke di poliklinik saraf RSUD Meuraxa Banda Aceh menyatakan hasil penelitian menunjukan bahwa ada dukungan keluarga dalam merawat pasien stroke berada pada kategori baik sebanyak $86,2 \%$ responden, dukungan informasionoal berada pada kategori baik sebanyak $84,5 \%$ responden, dukungan emosional berada pada kategori baik sebanyak 75,9\% responden, dukungan instrumental berada pada kategori baik sebanyak $82,8 \%$ responden, dukungan penilaian berada pada kategori baik $67,2 \%$ reponden.

\section{Kesimpulan}

Berdasarkan hasil penelitian dan pembahasan yang telah diuraikan sebelumnya mengenai hubungan dukungan keluarga dengan tingkat self esteem (harga diri) pada penderita stroke di Rumah Sakit Royal Prima Medan tahun 2019 dengan jumlah responden sebanyak 25 orang, maka diperoleh suatu kesimpulan yaitu Ada hubungan dukungan keluarga, informasional, penilaian, instrumental dan emosional dengan tingkat self esteem (harga diri)pada penderita stroke di Rumah Sakit Umum Royal Prima Medan tahun 2019.

Dengan ini keluarga sangat membantu dan berperan aktif dalam meningkatkan harga diri pada penderita stroke, karna keluarga sangat berperan penting untuk kesembuhan dan kelangsungan hidup pasien.

\section{Saran}

Bagi keluarga yang merawat pasien hendaknya dapat memberikan dukungan keluarga mulai dari dukungan informasional, penilaian, instrumental dan emosional yang baik sehingga dapat meningkatkan self esteem (harga diri) pada penderita stroke karena itu sangat membantu pasien dalam menciptakan gambaran positif mengenai kondisi dan keadaan saat ini sehingga pasien tidak merasa sangat buruk akan kondisinya dan menutup diri dari lingkungan.

Bagi responden diharapkan mengikuti segala macam jenis dan bentuk pengobatan stroke yang akan diberikan oleh keluarga dan tetap percaya dengan semua bantuan dan dukungan yang mereka berikan demi mempercepat proses penyembuhan.

Bagi peneliti selanjutnya diharapkan untuk melakukan penelitian ini dengan variabel-variabel lain yang berhubungan dengan dukungan keluarga dengan tingkat self esteem pada penderita stroke agar dapat digunakan sebagai informasi dan data selanjutnya.

\section{Referensi}

[1] Sunaryati, S.S., (2014). 14 Penyakit Paling Sering Menyerang dan Sangat Mematikan. Jogjakarta: Penerbit FlashBooks.

[2] Fahrizal,. Darliana, D. (2017). Dukungan Keluarga Dalam Merawat Pasien Stroke Di Poliklinik Saraf RSUD Meuraxa Banda Aceh. Jurnal Dukungan Keluarga dan Stroke. Volume 5. No.3

[3] Wayunah,. Saefulloh. M. (2016). Analisis Faktor Yang Berhubungan Dengan Kejadian Stroke Di Rsud Indramayu. Jurnal pendidikan keperawatan Indonesia. volume. 2, No.2 hal: 65-76.

[4] Ardhilla, C., \& Oktaviani, N. 2013. Diaskoljantroke (Diabetes Mellitus, Asam Urat, Kolesterol, Jantung \& Stroke). Yogyakarta: In Azna Books.

[5] Zarmi., Suri.M., Daryanto. (2017). Hubungan Kondisi Fisisk dan Mekanisme Koping Individu Dengan Harga Diri Penderita Pasca Stroke di Poliklinik Saraf RSUD Raden Mataher Jambi. Jurnal Akademi Baiturrahim. Vol.6. No.2.

[6] Okthavia, S. (2014). Hubungan Antara Dukungan Keluarga Dengan Tingkat Self Esteem Pada Penderita Stroke. Jurnal Psikologi Pendidikan Dan Perkembangan. Volume 3, No. 2.

[7] Hanum, P., Lubis. R. \& Rasmaliah. (2018). Hubungan Karakteristik dan Dukungan Lansia Dengan Kejadian Stroke Pada Lansia Hipertensi di RSU Adam malik Medan. Jumantik Volume 3, No.1. 
[8] Wati, F. D., \& Yanti, Y. (2018). Gambaran dukungan keluarga terhadap perubahan konsep diri pasien pasca stroke di poli neurologi Hanafiah Batusangkar 2018. REAL in Nursing Journal (RNJ) Research of Education and Art Link in Nursing Journal. Volume 1, No. 1.

[9] Hikmat, M,M., (2014). Metode Penelitian Dalam Perserpektif Ilmu Komunikasi dan Sastra. Yogyakarta: Graha Ilmu.

[10] Sugiyono., (2010). Metode Penelitian Kuantitatif Kualitatif dan R\&D.Bandung: Alfabeta.

[11] Rahman., Dewi., \& Setyopranoto. (2017).Dukungan keluarga dan kualitas hidup penderita stroke pada fase pasca akut di Wonogiri. Berita Kedokteran Masyarakat (BKM Journal of Community Medicine and Public Health) Volume 33 Nomor 8 Halaman 383-390.

[12] Fuady.,Sjattar \& Hadju. (2016).pengaruh pelaksanaan discharge planning terhadap dukungan psikososial keluarga merawat pasien stroke di rsup dr. wahidin sudirohusodo.JST Kesehatan, ISSN 2252-5416. Vol.6 No.2: $172-178$.

[13] Setyoadi., Nasution, H. T., \& Kardinasari. (2017). Hubungan Dukungan Keluarga dengan Kemandirian Pasien Stroke di Instalasi rehabilitasi medik rumah sakit dr. Iskak tulungagung.Majalah Kesehatan FKUB. Vol 4, No 3.

[14] Simbolon, P. 2017. hubungan dukungan keluarga dengan konsep diri pasien stroke di rumah sakit santa elisabeth medan. Jurnal Ilmu dan Teknologi Kesehatan, Vol 4 Nomor 2, hlm: $167-178$.

[15] Tatali, J. A., Mario. E. K., \& Rina. 2018. Hubungan Dukungan Keluarga dengan Tingkat Kemandirian Activity Daily Living (Adl) Pada Pasien Pasca Stroke di Poliklinik Neurologi RSU Gmim Pancaran Kasih Manado. e-journal Keperawatan (e-Kep) Volume 6 Nomor 1. 